2013, Vol. 2, Issue 2

\title{
GAPS IN INTERNATIONAL HUMAN RIGHTS AND HUMANITARIAN LAW IN RELATION TO ACCOUNTABILITY INVOLVING PRIVATE MILITARY AND SECURITY COMPANIES*
}

\author{
Elżbieta Karska*
}

\section{Introduction}

Private military servants have existed in the international community in different forms for some time. Private military and security companies (PMSCs) represent one contemporary form of such bodies. In the last decade, many States, international organizations, non-governmental organizations and transnational corporations have increasingly relied on PMSCs to perform military and security functions ${ }^{1}$.

* This Article is partly based on a speech delivered by the author at a side event to the $31^{\text {st }}$ International Conference of the Red Cross and Red Crescent on 'Protecting Civilians in Armed Conflict: Beyond the Montreux Document - International Developments in Private Military and Security Companies (PMSCs) regulation' on 30.11.2011 in Geneva. In this panel of experts discussion - including Professor Karska - the following also took part: Ambassador Valentin Zelwegger, Ph.D., Director of the Directorate of International Law and Legal Adviser, Swiss Federal Department of Foreign Affairs (DCAF); MarieLouise Tougas, Ph.D., Legal Adviser of the International Committee of the Red Cross; Anne-Marie Buzatu, J.D., Coordinator of DCAF's Privatisation of Security Programme; Michael Clarke, Director of Public Affairs of G4S plc and Adviser to the Temporary 
The use of PMSCs is widespread around the world. In addition to the types of activities they performed in the conflicts in Iraq and Afghanistan - which included detention, interrogation, protection of military facilities and convoys - they are performing an ever-increasing range of activities in these countries and throughout the globe. These include counter-narcotics activities, maritime and extractive industry security, humanitarian and combat operations. The outsourcing of core State activities, particularly in conflict and post-conflict situations, has given rise to a number of challenges with regard to international humanitarian and human rights law ${ }^{2}$.

Steering Committee of the International Code of Conduct for Private Security Providers; Hassan Zerán, Third Secretary, Permanent Mission of Chile to the United Nations and other International Organizations in Geneva.

Elements of Professor Karska's speech have been further used in: Submission by the Working Group on the use of mercenaries as a means of impeding the exercise of the right of peoples to self-determination for Open-ended intergovernmental working group to consider the possibility of elaborating an international regulatory framework on the regulation, monitoring and oversight of the activities of private military and security companies, Second session, Geneva, 13-17 August 2012, UN Doc. A/HRC/WG.10/2/CRP.1, 6.8.2012.

This article does not reflect the official statement of the whole UN Working Group on the use of mercenaries as a means of violating human rights and impeding the exercise of the right of peoples to self-determination and constitutes merely the personal opinion of the Author.

** J.D., Ph.D., Professor of Law, Faculty of Law and Administration, Cardinal Stefan Wyszyński University in Warsaw; Member of the UN Working Group on the use of mercenaries as a means of violating human rights and impending the exercise of the right of peoples to self-determination, UN Human Rights Council, Geneva.

1 On military services outsourcing historical development, see, for example, M. Cottier, Elements for Contracting and Regulating Private Security and Military Companies, 'International Review of the Red Cross', 2006, No. 863, p. 637; Ch. Kinsey, Corporate Soldiers and International Security: The Rise of Private Military Companies, Rutledge, London-New York 2006, pp. 72-133; A. Leander, Eroding State Authority?: Private Military Companies and the Legitimate Use of Force, Centro Militare di Studi Strategici, Roma 2006, pp. 29-72; T. K. Nandi, S. Mohanty, The Emergence of Private Military Firms and Their Impact on Global Human Rights, GRIN Verlag, Norderstedt 2010, pp. 3-21; P. W. Singer, Corporate Warriors. The Rise of Private Military Industry, Cornell University Press, Ithaca 2004, pp. 49-73.

2 The scope of activity provided by PMSCs and their typology is further discussed, for example, in: D.D. Avant, The Market for Force: The Consequences of Privatizing Security, Cambridge University Press, Cambridge 2006, pp. 16-22; Ch. Kinsey, op. cit., pp. 8-34; P.W. Singer, Corporate Warriors: The Rise of the Privatized Military Industry and Its Ramifications for International Security, 'International Security', 2001-2002, Vol. 3, 


\section{Gaps in international humanitarian law}

Unfortunately, the current regulatory framework does not adequately answer such challenges. It leaves significant gaps at both international and national levels, particularly with regard to accountability and effective remedies for victims.

International humanitarian law, the law applicable in armed conflicts, does not address the question of outsourcing inherently State functions to PMSCs. Accordingly, international humanitarian law has nothing to say about whether it is legal or illegal to outsource, for example, detention and interrogation functions to a private company. Indeed, international humanitarian law does not even forbid PMSCs from undertaking a direct combat role. International humanitarian law does not forbid any activity of PMSCs. Conversely, international humanitarian law does prohibit such activities when undertaken by mercenaries. Appropriate regulations in the latter case are provided by the Additional Protocol to the Geneva Conventions of 12.8.1949, and relating to the Protection of Victims of International Armed Conflicts (Protocol I) of 8.6.19773 and by the International Convention against the Recruitment, Use, Financing and Training of Mercenaries of 4.12.19894. The Convention for the Elimination of Mercenarism in Africa represents a regional for prohibiting such activities and was adopted by the Organization of African Unity in Libreville on 3.7.19775. Given the definition of a mercenary, these legal measures do not apply directly to PMSCs and their workers. Whilst the definition of a mercenary and a worker of a PMSC may coincide in certain situations, this does not mean that they are synonymous. It is impossible to equate them ${ }^{6}$.

pp. 198-202; M. Terlikowski, Prywatne firmy wojskowe w amerykańskiej operacji stabilizacji Iraku [Private Military Companies in the US Stabilization Operation in Iraq], Materiały Studialne, No. 9, The Polish Institute of International Affairs, Warsaw 2008, pp. 8-10.

31125 UNTS 3.

42163 UNTS 75.

51490 UNTS 95.

6 See, for example, Ch. Kinsey, op. cit., pp. 111-134. See also International Committee of the Red Cross, Contemporary challenges to IHL - Privatization of war: 
Mercenarism is also indirectly regulated by the provisions of the Hague Convention V respecting the Rights and Duties of Neutral Powers and Persons in Case of War on Land of 18.10.19077. Article 4 of this Convention stipulates that: "Corps of combatants cannot be formed, nor recruiting agencies opened on the territory of a neutral Power to assist the belligerents". In this context, it is rightly mentioned that:

The neutral Power thus has an obligation to prevent such activities from occurring on its territory. However, it cannot be held responsible where individuals cross the border of their own accord to offer their services to the belligerents. The Hague Convention $\mathrm{V}$ is considered to represent customary law, which means that it is applicable to all States. Article 4 in effect creates an obligation for States to prevent the formation of mercenary groups on their territory for the purpose of intervention in an armed conflict to which they have chosen to remain neutral. If they fail to do so, they are in violation of their obligations under international law ${ }^{8}$.

However, the nature of the activities carried out by PMSC employees in armed conflict situations defines their rights, obligations, protections and the legal consequences deriving from their conduct.

The activities of PMSCs and their employees in armed conflicts are subject to international humanitarian law, just like the activities of any other individuals in armed conflicts. Furthermore, States Parties to the four Geneva Conventions ${ }^{9}$ have the obligation to ensure respect

overview, 1.8.2012, available at: http://www.icrc.org/eng/war-and-law/contemporarychallenges-for-ihl/privatization-war/overview-privatization.htm (accessed on 1.11.2012). There are of course different views in this matter. However, they are not expressed in the legal field. See, for example, I. Wing, Private Military Companies and Military Operations, Working Paper No. 138, Land Warfare Studies Centre, Duntroon 2010, pp. 13-15.

736 Stat. 2310, TS No. 540.

8 The Impact of Mercenary Activities on the Right of Peoples to Self-Determination, Fact Sheet No. 28, Office of the United Nations High Commissioner for Human Rights, United Nations Office at Geneva, Geneva 2002, pp. 12-13.

9 Convention (I) for the Amelioration of the Condition of the Wounded and Sick in Armed Forces in the Field, Geneva, 12.8.1949, 75 UNTS 31; Convention (II) for the Amelioration of the Condition of Wounded, Sick and Shipwrecked Members of Armed Forces at Sea, Geneva, 12.8.1949, 75 UNTS 85; Convention (III) relative to the Treatment of Prisoners of War, Geneva, 12.8.1949, 75 UNTS 135; Convention (IV) relative to the Protection of Civilian Persons in Time of War, Geneva, 12.8.1949, 75 UNTS 287. 
for international humanitarian law, an obligation which extends to all those over whom they have authority and to the representatives of their authority. International humanitarian law also obliges States to take all necessary measures to suppress all acts contrary to the four Geneva Conventions and to put on trial or extradite for trial those who commit grave breaches of the Geneva Conventions ${ }^{10}$.

Equally, given their status as legal persons, PMSCs can be brought to criminal justice on the basis of international law provisions. It is a Nuremberg standard based on Articles 9 and 10 of the Charter of the International Military Tribunal (Nuremberg Tribunal) ${ }^{11}$. Such activities do not exclude the possibility to bring PMSCs to justice for violations of international law and to hold them responsible on the basis of national law provisions forming part of the State's civil law and administrative law system $^{12}$. It is symptomatic that corporate criminal responsibility in the sphere of international law is nowadays discussed in academic writings against a factual background that has witnessed a growth in the share and activity of private corporations, including PMSCs, in the conduct of armed conflicts ${ }^{13}$.

Despite common reference to the term "mercenaries" to describe PMSCs and the fact that, in some cases, PMSC employees meet the criteria of mercenaries, international instruments governing mercenary

10 For more, see E. Socha, International Responsibility of Individual for Breaches of Humanitarian Law, 'Polish Yearbook of International Law', 2002-2003, Vol. 26, pp. 67-84.

${ }_{11}$ The Charter is an annex to the Agreement for the Prosecution and Punishment of the Major War Criminals of the European Axis, 8.8.1945, 82 UNTS 280. On the responsibility of national legal persons on the basis of the provisions of international criminal law and provisions of national law in States whose systems of law are familiar with the institution of corporate penal responsibility, see also, for example, J.E. Nijman, The Concept of International Legal Personality. An Inquiry Into the History and Theory of International Law, T.M.C. Asser Press, The Hague 2004, p. 406; W.A. Schabas, The UN International Criminal Tribunals: The Former Yugoslavia, Rwanda and Sierra Leone, Cambridge University Press, Cambridge 2006, p. 139.

12 A. Clapham, Human Rights Obligations of Non-State Actors, Oxford University Press, Oxford 2006, pp. 299-309; K. Karski, Osoba prawna prawa wewnętrznego jako podmiot prawa międzynarodowego [Legal Person of Internal Law as Subject of International Law], University of Warsaw Press, Warsaw 2009, pp. 249-256.

${ }_{13}$ See, for example, K. Karski, op. cit., p. 253-253; J.C. Zarate, The Emergence of a New Dog of War: Private International Security Companies, International Law, and the New World Disorder, 'Stanford Journal of International Law', 1998, Vol. 34, p. 75. 
activities do not normally apply to PMSCs. This is because the employees of PMSCs do not usually meet the legal definition of mercenaries, as set out in the First Additional Protocol to the four Geneva Conventions ${ }^{14}$, the International Convention against the Recruitment, Use, Financing and Training of Mercenaries ${ }^{15}$ or the Convention for the Elimination of Mercenarism in Africa ${ }^{16}$ :

For example:

- although some PMSC employees are reported to have directly participated in hostilities, the majority do not conduct direct combat operations;

- PMSC employees are often nationals or residents of one of the State parties to the conflict;

- PMSC employees sometimes operate within the military chain of command and are deemed to be members of the armed forces of a party to the conflict.

As mentioned above, this is merely an exemplary enumeration. Problems have also been encountered by national courts when seeking to bring to justice people employed, enlisted or recruited by PMSCs. One such case took place before an Italian court, which heard that people were sending private security guards to work in Iraq. The accused were acquitted and one of the first investigations conducted by the court was to examine their activity to ascertain whether or not it could be classified, in a conventional definition, as constituting the recruitment of mercenaries. The court found in the negative ${ }^{17}$. Commenting on this case, Valeria Eboli notes as follows:

A description of the envisaged activity, as bodyguards or armed security officers, was contained in some specific Guidelines. The enlisted persons were allowed to use the weapons only to protection of VIPs, self-defence or the protection of the local population and only if the security agent witnessed acts of violence against the individuals in need of protection.

14 Article 47 of the Protocol.

15 Article 1 of the Convention.

16 Article 1 of the Convention.

17 Judgment of the Assize Court of Bari on the Case Prosecutor v. Giovanni Piero Spinelli and Salvatore Stefio for the Crimes provides by Articles 110 and 288 of the Criminal Code, 16.7.2010. 
In the view of the Court, the Guidelines excluded the possibility of direct participation of the hostilities. (...) It seems difficult to share the view of the Court on the fact that an eventual intervention of the contractors in defence of the civilians, as provided for in the Guidelines on their employ, does not constitute a direct participation in the hostilities (...). The Assize Court of Bari determined that this kind of activity was excluded from the coverage of Article 288 [Italian Criminal Code] because the accused did not enlist the employees as combatants but for reasons not connected to the conduct of military operations, even thought the envisaged activity was connected to the existence of an armed conflict (as the VIPs the subject of security functions worked in the framework of post-conflict reconstruction).

This author rightly argued that:

The Court's decision is important because in Italy there is no law regulating the activities of private military and private security companies. It is clear from this decision that existing law may not adequately cover all exigencies relevant to contemporary armed conflicts ${ }^{18}$.

\section{Gaps in human rights law}

In addition to international humanitarian law, human rights law provides protection both in armed conflict situations and when PMSCs operate outside the context of armed conflict. For example, human rights law would regulate the involvement of PMSCs in operations such as disaster relief or humanitarian aid - situations that may also pose serious risks to human rights ${ }^{19}$.

18 V. Eboli, Unauthorized Enlisting or Arming in the Service of a Foreign State, 'Yearbook of International Humanitarian Law', 2010, Vol. 13, pp. 538-540. See also V. Eboli, Court of Assize of Bari, Order of 24.4.2008 committing Salvatore Stefio for trial for alleged violation of Article 288 of the Penal Code (Unauthorised Recruiting or Arming on Service of a Foreign State), 'Yearbook of International Humanitarian Law', 2008, Vol. 11, pp. 511-512.

19 For more, see T. Cross, The Humanitarian Community and the Private Sector [in:] K.M. Cahill (ed.), 'The Pulse of Humanitarian Assistance', Fordham University Press, New York 2007, p. 100; B. Perrin, Humanitarian Assistance and the Private Security Debate: An International Humanitarian Law Perspective: On the Edges of Conflict, 'Canadian Red Cross', pp. 3-32, available at: http://www.redcross.ca/cmslib/general/oteoc_ben_perrin. 
While PMSCs and their employees are not normally deemed to be direct subjects of human rights law, States are obliged to take appropriate measures and to exercise due diligence to prevent, punish, and investigate human rights violations and to redress the harm caused by any violations involving PMSCs.

Although States are obliged to ensure that PMSCs and their employees respect both international humanitarian law and human rights law, this system has proven ineffective in providing accountability to victims. In the last several years, it has been possible to identify various obstacles to accountability that suggest the existence of legal lacunae at an international level that remain to be addressed. I will only mention a few.

As regards individual responsibility, States often grant immunity to the employees of PMSCs from jurisdiction in the country wherein they operate. This means that such individuals cannot be held responsible for their involvement in violations of humanitarian and human rights law in the territorial state.

International justice is an equally unviable option. The jurisdiction of the International Criminal Court (ICC) is limited, preventing the Court in many cases from exercising jurisdiction over war crimes committed by the employees of $\mathrm{PMSCs}^{20}$. A similar conclusion is reached following an analysis of the jurisdiction of the European Court of Human Rights and other regional courts in human rights systems.

As regards State responsibility, PMSCs are usually not absorbed into the State's armed forces and are, therefore, not subject to the military chain of command and the consequential accountability mechanisms. Furthermore, the obligation of States to try or extradite those who have committed grave breaches of the four Geneva Conventions and the First Additional Protocol relates only to international armed conflicts, whereas such armed conflicts rarely exists in the contemporary global environment. Finally, States sometimes fail to fulfil their due-diligence related obligations with regard to human rights law.

pdf (accessed on 1.11.2012); F. Schreier, M. Caparini, Privatising Security: Law, Practice and Governance of Private Military and Security Companies, Occasional Paper No. 6, Geneva Centre for the Democratic Control of Armed Forces, Geneva 2005, p. 93.

20 On the limits of the ICC activity see, for example, The Impact of Mercenary Activities on the Right of Peoples to Self-Determination..., p. 21. 


\section{Gaps in national law}

Simultaneously, regulatory tools are sorely lacking at the national level. Based on the experience and country visits of the 'UN Working Group on the use of mercenaries as a means of violating Human Rights and impending the exercise of the right of peoples to self-determination' (the UN Working Group on Mercenaries) ${ }^{21}$, the Working Group concluded that, even where national legislation exists, it often falls short of adequate standards as regards the registering and licensing of such companies, regulation of the types of functions they may perform, creating mechanisms to ensure their accountability and providing remedies to victims for any violations. The limitations of national law are particularly felt in the increasingly transnational nature of many PMSC activities ${ }^{22}$.

21 The UN Working Group on Mercenaries was established by the UN Commission on Human Rights in 2005 (resolution 2005/2). It consists of five independent experts. The seats are distributed - each one - among the UN's regional groups. At the present moment, the UN Working Group on Mercenaries is established by the UN Human Rights Council to which it provides - the same as to the UN General Assembly - reports. In 2011 UN Human Rights Council - following the termination of the term of office of previous members - the UN Working Group on Mercenaries elected its new composition. On the subject of the UN Working Group on Mercenaries see, for example, J. Cockayne, E. Speers Mars, I. Cherneva, A. Gurin, Sh. Oviedo, D. Yaeger, Beyond Market Forces: Regulating the Global Security Industry, International Peace Institute, New York 2009, pp. 9 and 51-53.

22 For more, on the subject of transnational corporation activity, including PMSCs, as regards matters which could violate human rights and international humanitarian law, see: E. Karska, Korporacje transnarodowe wobec międzynarodowego prawa humanitarnego [Transnational Corporations vis-à-vis International Humanitarian Law], [in:] J. Menkes, T. Gardocka (eds), 'Korporacje transnarodowe: Jeden temat, różne spojrzenia' ['Transnational Corporations: One Subject, Many Views'], University of Social Psychology Press 'Academica', Warsaw 2010, pp. 151-175; K. Karski, Zakres podmiotowości korporacji transnarodowej $w$ prawie międzynarodowym [The Scope of Transnational Corporations' Subjectivity in International Law], [in:] J. Menkes, T. Gardocka (eds), op. cit., pp. 176-210; A. Mężykowska, Prawa i odpowiedzialność korporacji transnarodowych w świetle międzynarodowego prawa praw człowieka [Rights and Responsibility of Transnational Corporation in the Light of International Law of Human Rights], [in:] J. Menkes, T. Gardocka (eds), op. cit., pp. 233-249. 
The UN Working Group on Mercenaries is convinced that, in order to avoid impunity and to ensure accountability for serious violations of international humanitarian and human rights law, an adequate monitoring and oversight mechanism is necessary for PMSCs, including licensing and vetting procedures provided by national law.

The UN Working Group on Mercenaries supports efforts to improve this situation, such as the International Code of Conduct for Private Security Service Providers, since such efforts will lead to an improvement in standards across the industry ${ }^{23}$. It is most crucial to monitor new developments regarding the forthcoming governance and oversight mechanism. However, it is also worth pointing out that the International Code of Conduct, as a self-regulatory tool, can be only effective if it is able to ensure accountability for violations of international humanitarian and human rights law with the support of an effective and non-industry oversight and auditing of the grievance mechanism.

\section{What is the solution for gaps?}

In May 2011, the first session of the open-ended intergovernmental working group to consider the possibility of elaborating an international regulatory framework on the regulation, monitoring and oversight of the activities of private military and security companies (OEIWG) took place in Geneva. The international community was encouraged to observe that the majority of States present at the meeting recognized the need to regulate the activities of $\mathrm{PMSCs}^{24}$. Whether such regulation will take

23 On 1.10.2012, there were 511 PMSC signatories from 63 states. Text available at: http://www.icoc-psp.org/ (accessed on 1.11.2012). On the Code of Conduct see, for example, Ch. Lehnardt, Private Militärfirmen und völkerrechtliche Verantwortlichkeit [Private Military Companies and International Legal Responsibility], Mohr Siebeck, Túbingen 2011, pp. 46, 48. States have also declared their activity to be consistent with the rules laid down in this document. See Human rights and democracy: the 2011 Foreign and Commonwealth Office Report, United Kingdom Foreign and Commonwealth Office, London 2012, pp. 107-108.

24 UN Human Rights Council in resolution 15/26 of 1.10.2010 decided "to establish an open-ended intergovernmental working group (OEIWG) with the mandate to consider the possibility of elaborating an international regulatory framework, including, inter alia, 
the form of an international convention along the lines proposed by the UN Working Group on Mercenaries remains to be seen $^{25}$, as discussions remain on-going. A second meeting of the inter-governmental working group, held in August 2012, was progressive ${ }^{26}$.

\subsection{Definition of PMSC}

A universally recognized international convention seems to be the best of the first steps towards a solution of the gaps remaining in both international and national law. A draft of such a convention in fact represents the primary document in contemporary international law which provides a definition of a PM and/or Security Company. Article 2(a) thereof notes that this concept: "refers to a corporate entity which provides on a compensatory basis military and/or security services by physical persons and/or legal entities"27. Military services refers to: specialized services related to military actions including strategic planning, intelligence, investigation, land, sea or air reconnaissance, flight operations of any type, manned or unmanned, satellite surveillance, any kind of knowledge transfer with military applications, material and technical support to armed forces and other related activities ${ }^{28}$. Similarly, the concept of security services refers to: armed guarding or protection of buildings, installations, property and people, any kind of knowledge transfer with security and policing applications, development and implementation of informational security measures and other related

the option of elaborating a legally binding instrument on the regulation, monitoring and oversight of the activities of private military and security companies (PMSCs), including their accountability, taking into consideration the principles, main elements and draft text as proposed by the Working Group on the use of mercenaries as a means of violating human rights and impeding the exercise of the right of peoples to self-determination". $1^{\text {st }}$ session of the OEIWG took place from 23-27.5.2011 in Geneva.

25 Draft of a possible Convention on Private Military and Security Companies (PMSCS) for consideration and action by the Human Rights Council Prepared by the Working Group on the use of mercenaries as a means of violating human rights and impeding the exercise of the right of peoples to self-determination, UN Doc. A/HRC/WG.10/1/2.

$262^{\text {nd }}$ session of the OEIWG took place from 13-17.8.2012 in Geneva.

27 Article 2(a) of the Draft Convention.

28 Article 2(b) of the Draft Convention. 
activities $^{29}$. Despite the absence of unanimous support for this definition, it nevertheless represents a good starting point for future discussion on creating a legally binding definition ${ }^{30}$.

\subsection{State functions}

The importance of adopting such a convention is not only connected with the aforementioned gaps in international and national law, but it is also necessary for the international legal system as a whole. As the first conventional source of international law, it provides a definition of inherently State functions. These are defined as:

[f] unctions which are consistent with the principle of the State monopoly on the legitimate use of force and that a State cannot outsource or delegate to PMSCs under any circumstances. Among such functions are direct participation in hostilities, waging war and/or combat operations, taking prisoners, law-making, espionage, intelligence, knowledge transfer with military, security and policing application, use of and other activities related to weapons of mass destruction and police powers, especially the powers of arrest or detention including the interrogation of detainees and other functions that a state party considers to be inherently State functions $s^{31}$.

29 Article 2(c) of the Draft Convention.

30 According to the legally non-binding definition provided by the "Montreux Document" of 2008: “PMSCs' are private business entities that provide military and/or security services, irrespective of how they describe themselves. Military and security services include, in particular, armed guarding and protection of persons and objects, such as convoys, buildings and other places; maintenance and operation of weapons systems; prisoner detention; and advice to or training of local forces and security personnel”. While: "'Personnel of a PMSC' are persons employed by, through direct hire or under a contract with, a PMSC, including its employees and managers". Montreux Document on Pertinent International Legal Obligations and Good Practices for States related to Operations of Private Military and Security Companies during Armed Conflict, Montreux, 17.9.2008, para. 9(a)(b). UN Doc. A/63/467-S/2008/636, Annex. For more, see, for example, H. Tonkin, State Control over Private Military and Security Companies in Armed Conflict, Cambridge University Press, Cambridge 2011, pp. 35, 84, 129-134, 145, 153. Currently, 42 States and 1 international organization (the EU) support this declaration.

31 Article 2(i) of the Draft Convention. 
It seems that the Draft provides a very traditional understanding of State functions. Despite serious disagreements, it reflects classical statements of the law of nations.

The possible convention also establishes an important licensing regime which:

[r]efers to a regime of measures related to the issuing of a licence, redrafting documents, confirming licence, suspension of licence on grounds of violation of obligations and provisions of the licence, cessation or resumption of licence, withdrawal of licence, control of licensing bodies over the observance of obligations and terms of licence by licensees in their activities, introduction of licence registries as well as an established form of provision of information from licence registries and other licensing information by interested persons ${ }^{32}$.

According to the convention "licence (authorisation, permit): refers to a special document authorizing specified activities under the strict observance of licensing terms and obligations, which is issued by a licensing body to a legal entity or a physical person" 33 and licence registry which "refers to the data pool related to the issuing of a licence, redrafting documents, confirming licence, suspension or resumption of licence, and withdrawal of licence; a licence registry must operate pursuant to written minimum standard"34.

\subsection{Obligations in national law}

Pursuant to Article 7 of the future convention, each State party shall take legislative, judicial, administrative and other measures as may be necessary to ensure that PMSCs and their personnel are held accountable in accordance with the convention and to ensure respect for and protection of international human rights law and humanitarian law. Each state party shall ensure that PMSCs and their personnel apply due diligence to ensure that their activities do not contribute directly or indirectly to violations of human rights and international humanitarian

32 Article 2(e) of the Draft Convention.

33 Article 2(d) of the Draft Convention.

34 Article 2(f) of the Draft Convention. 
law. The superiors of PMSC personnel, such as: (a) Government officials, whether military commanders or civilian superiors; or (b) Directors or managers of PMSCs; may be liable for crimes contrary to international law committed by PMSC personnel under their effective authority and control, as a result of their failure to properly exercise control over them, in accordance with the rules of international law. No contractual clause shall be interpreted as permitting the evasion of such international law responsibility on the part of superiors ${ }^{35}$.

Part III of the Convention provides specific legislative regulation, which each State party shall develop and adopt in national legislation to adequately and effectively regulate the activities of PMSCs ${ }^{36}$. In fact this part belongs to the most contentious amongst States participating in the intergovernmental process of its adoption. Many States are afraid of excessive supervision over national mechanisms of control. Article 13 of that Part of the Convention provides that:

[e]ach State party shall:

(a) Establish a comprehensive domestic regime of regulation and oversight over the activities in its territory of PMSCs and their personnel including all foreign personnel, in order to prohibit and investigate illegal activities as defined by the Convention as well as by relevant national laws;

(b) In order to ensure that administrative, regulatory, law enforcement and other bodies, implementing the regime of regulation and oversight over the activities of PMSCs and their personnel, are able to cooperate and exchange information at national and international levels, there should be established, at the domestic level, a register and/or a governmental body which shall act as a national centre for collection, analysis and exchange of information concerning possible violations of national and international law so as to provide operative information about the activities of $\mathrm{PMSCs}^{37}$.

Additionally States parties shall apply practical measures for sharing information on companies providing military and security services outside their territories and for establishing control over the provision of such

35 Article 7.1-3 of the Draft Convention.

36 Article 12 of the Draft Convention.

37 Article 13.1(a)-(b) of the Draft Convention. 
services, as consistent with the safeguards aimed at ensuring the proper use of information without impeding their legal implementation in any way. Such measures may include the provision of information or reports on the use of transborder military and security services by persons and legal entities, for example companies. When establishing a domestic regime for regulation and oversight in accordance with the provisions of this article and in compliance with other articles of the Convention, all States parties agree to be guided by the respective initiatives of regional, interregional and multilateral organizations. States parties shall endeavour to develop and encourage global, regional, subregional and bilateral cooperation among judicial bodies, law-enforcement agencies and financial regulation bodies in order to monitor and control any use of force by PMSCs. States parties shall investigate reports of violations of international humanitarian law and human rights norms by private military companies and private security companies and ensure civil and criminal prosecution and punishment of offenders. States parties shall take appropriate action against companies that commit human rights violations or engage in any criminal activity, inter alia by revoking their licences and reporting to the Committee on the record of activities of these companies ${ }^{38}$.

\subsection{Monitoring mechanism}

Naturally, the crucial point of the Convention refers to the system for monitoring licensing imports and exports of military and security services the draft Convention firstly provides for the establishment of a Committee on the Regulation, Oversight and Monitoring of $\mathrm{PMSCs}^{39}$. According to Article 15.2:

[e]ach State party which imports or exports private military and security services shall publicize their scope and activities, keep the Committee informed about its licensing regime and provide regular and updated information on any changes and supplements to the import or export of

38 Article 13.2-6 of the Draft Convention.

39 Article 29 of the Draft Convention. 
these services, including details of any subsidiaries or holding companies of the PMSC in question ${ }^{40}$.

Additionally, Article 30 provides for the creation of an International Register of PMSCs, which states as follows:

States parties request the Committee to establish and maintain an International Register of PMSCs operating on the international market, based on information provided by States parties. Each State party shall provide annually for the Register data on imports and exports of military services of PMSCs and standardized information on PMSCs registered in and licensed by the State party ${ }^{41}$.

The draft Convention provides for a fairly strict system for monitoring the gaps in international and national law. It establishes a system of reports to be submitted by State parties to the Secretary-General of the United Nations for consideration by the Committee. Such report shall detail the legislative, judicial, administrative or other measures which were adopted in order to give effect to the provisions of the Convention ${ }^{42}$. The Committee shall decide any guidelines applicable to the content of the reports ${ }^{43}$. Each report shall be considered by the Committee, which shall make such suggestions and general recommendations on the report as it may consider appropriate and shall forward these to the State party. The Committee may request further information from States parties relevant to the implementation of the Convention ${ }^{44}$.

Another monitoring system provided for by the Draft Convention is the inquiry procedure, complaints against parties or individual and group petitions. The first of the aforementioned occurs if the Committee receives reliable information indicating grave or systematic violations of the provisions set forth in the Convention, following which the Committee shall invite the State in which the reported offences occurred and/or the State in which the PMSC reportedly involved in such offences is registered

40 Article 15.2 of the Draft Convention.

41 Article 30.1-2 of the Draft Convention.

42 Article 31.1 of the Draft Convention.

43 Article 31.2 of the Draft Convention.

44 Article 32.1 of the Draft Convention. 
to cooperate in the examination of the information and, to this end, to submit observations with regard to the information concerned ${ }^{45}$. Taking into account any observations which may have been submitted by the State(s) concerned, and any other relevant information available to it, the Committee may, if it decides that this is warranted, designate one or more of its members to make a confidential inquiry and to report to the Committee urgently ${ }^{46}$. If a matter referred to the Committee in accordance with Article 33 is not resolved to the satisfaction of the State parties concerned, the Committee may, with the prior consent of the State parties concerned, appoint an ad hoc Conciliation Commission comprising five persons who may or may not be members of the Committee. The members of the Commission shall be appointed with the unanimous consent of the parties to the dispute, and in good office shall be made available to the States concerned with a view to an amicable solution of the matter on the basis of respect for this Convention ${ }^{47}$.

The second method is provided for by Article 34 - Complaints against parties - according to which a State party to this Convention may at any time declare under this article that it recognizes the competence of the Committee to receive and consider communications to the effect that a State party claims that another State party is not fulfilling its obligations under this Convention. Such communications may be received and considered according to the procedures laid down in this article only if submitted by a State party which has made a declaration recognizing in regard itself the competence of the Committee. No communication shall be dealt with by the Committee under this article if it concerns a State party which has not made such a declaration. Communications received under this article shall be dealt with in accordance with the following procedure:

(a) If a State party to this Convention considers that another State party is not giving effect to the provisions of this Convention, it may bring the matter to the attention of the Committee. The Committee shall than transmit the complaint to the party concerned. Within three months, the receiving party shall submit to the Committee written

45 Article 33.1 of the Draft Convention.

46 Article 33.2 of the Draft Convention.

${ }^{47}$ Article 35.1(a) of the Draft Convention. 
explanations or statements clarifying the matter and the remedy, if any, that may have been taken by that party;

(b) If the matter is not adjusted to the satisfaction of both parties, either by bilateral negotiations or by any other procedure open to them, within six months after the receipt by the receiving party of the initial complaint, either State shall have the right to refer the matter again to the Committee by notifying the Committee and also the other party;

(c) The Committee shall deal with a matter referred to it in accordance with paragraph 2 of this article ${ }^{48}$ after it has ascertained that all available domestic remedies have been invoked and exhausted in the case, in conformity with the generally recognized principles of international law. This shall not be the rule where the application of the remedies is unreasonably prolonged ${ }^{49}$.

Last but not least, Article 37 contains a mechanism which is worthy of attention - Individual and group petitions - a State party may, at the time of ratification of this Convention or at any time afterwards, declare that it recognizes the competence of the Committee to receive and consider communications from or on behalf of individuals subject to its jurisdiction claiming to be victims of a violation by this State party of provisions of this Convention. The Committee shall not admit any communication concerning a State party which has not made such a declaration ${ }^{50}$.

\section{Conclusions}

It is submitted that a general consensus could be found for the proposition that the ever-expanding activities of PMSCs continue to raise a number of challenges, for regulators, for companies seeking to fulfil their obligations and for those concerned about the human rights of individuals who come into contact with PMSCs.

48 According to Article 34.2 of the Draft Convention: "the Committee shall hold closed meetings when examining complaints under this Article".

49 Article 34.1 of the Draft Convention.

50 Article 37.1 of the Draft Convention. 
Equally, there is common consent that providing security to its people constitutes a fundamental responsibility of the State and that the outsourcing of security to private military and security companies creates risks for human rights which, in turn, necessitates the regulation of such activities.

While PMSCs have a duty to respect human rights, it is the obligation of the State to ensure that victims are provided with adequate remedies in the event that violations occur. English and American jurisprudence evidences a legal maxim stating that: for every right, there is a remedy; where there is no remedy, there is no right ${ }^{51}$. Depriving victims of remedies is tantamount to denying their human rights, an unacceptable result which should be avoided at all costs ${ }^{52}$.

The international community should continue to search for a solution that would allow us to end impunity and to ensure effective remedies to victims of violations of international law resulting from the activities of private military and security companies.

51 Sir W. Blackstone, Commentaries on the Laws of England, $1^{\text {st }}$ Edition, Clarendon Press, Oxford 1765-69, pp. 42-43, 116, 109, 124, 126, 129-144, 161-162, 271-273. See also J. Welch, British Experience with the Human Rights Act: An Effective Domestic Remedy, [in:] 'Concepts of General Domestic Remedy and Simplified Procedure for Amending the Convention in Post-Interlaken Process: $4^{\text {th }}$ Warsaw Seminar, 9-10 September 2010: In Memory of Professor Krzysztof Skubiszewski (1926-2010)', Krajowa Szkoła Administracji Publicznej, Warsaw 2010, pp. 86-96. For US practice, see Marbury v. Madison, 5 U.S. (1 Cranch) 137, 162-163 (1803). See also Appeal of Wimtle, 781 A.2d 995, 997 (N.H. 2001); Baugher v. Beaver Constr. Co., 791 So.2d 932, 934 (Ala. 2000); Helman v. State, 784 A.2d 1058, 1070 (Del. 2001); Holeton v. Crouse Cartage Co., 748 N.E.2d 1111, 1132 (Ohio 2001) (J. Cook,, dissenting); McAlister v. Schick, 588 N.E.2d 1151, 1157 (Ill. 1992); McIntosh v. Melroe Co., 729 N.E.2d 972, 975, 976 (Ind. 2000); Mohundro v. Alcorn County, 675 So.2d 848, 852 (Miss. 1996); Meech v. Millhaven W., Inc., 776 P.2d 488, 497 (Mont. 1989); Jensen v. Whitlow, 51 P.3d 599, 601 (Or. 2002); Kennedy v. Cumberland Engineering Co., 417 A.2d 195, 201 (R.I. 1984) (J. Murray, dissenting).

52 For more on the European aspect, see I. Reine, Follow-up to the Recommendation Rec(2006)6 on the Improvement of Domestic Remedies: Some Remarks by the former Rapporteur of the DH-PR, [in:] 'Concepts of General Domestic Remedy...', pp. 17-23; M. Balcerzak, Domestic Remedies and the Obligation to Execute the Court's Judgments, [in:] 'Concepts of General Domestic Remedy...', pp. 24-37; E. Kerševan, Constitutional Complaint as a General Domestic Remedy and the Shared Responsibility to Implement the European Convention of Human Rights, [in:] 'Concepts of General Domestic Remedy...', pp. $48-78$. 